\title{
La Conquistadora
}

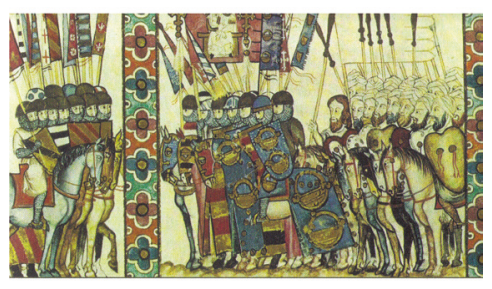

LA CONQUISTADORA

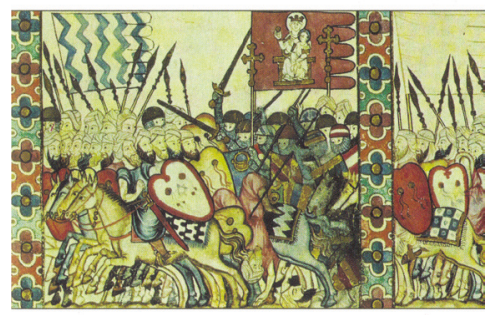

The Virgin Mary at War and Peace in the Old and New Words
FICHA BIBLIOGRÁFICA

Amy G. Remensnyder, La Conquistadora. The Virgin Mary at War and Peace in the Old and New Worlds. New York, Oxford University Press, 2014, 470 págs. ISBN 978-01-99893-00-3

\section{María Jesús Fuente Universidad Carlos III de Madrid}

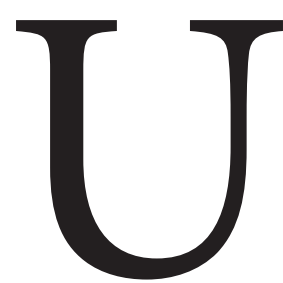

n día del verano de 1992 la autora de este libro visitaba un famoso lugar de peregrinación mejicano, Chimayó, y observando curiosamente los alrededores del santuario se encontró con la "conquistadora". Su imagen, en un muro de piedra detrás del santuario, estaba representada en una cerámica, y bien acompañada por otras imágenes de santos tan conocidos e importantes como Santiago, Francisco de Asís o la Virgen de Guadalupe. No era solo en Chimayó donde podía encontrar a la "conquistadora", no lejos de allí, en la catedral de Santa Fe, Nuevo México (USA), también podía haberla encontrado.

Amy Remensnyder, conociendo el modelo de madre, amorosa y pacífica, de la Virgen María, se planteó la pregunta de cómo era posible que ese icono pudiera recibir el nombre de "la conquistadora". Esa pregunta la llevó a interesarse por el papel que María había jugado en tiempos de guerra y de conquista, es decir, la llevó a escribir este libro. Aunque el encuentro 
con la "conquistadora" fuera en México, la autora, por su condición de medievalista, comprendió que los orígenes de ese culto no podían partir más que de la reconquista hispana. De ahí que la primera de las tres partes de las que consta el libro se dedique a "la Virgen y la Reconquista". Las otras dos secciones tocan dos tiempos y dos espacios en los que la "conquistadora" tuvo un impacto extraordinario: la segunda parte está destinada a estudiar el papel que lo espiritual en general y la Virgen en particular jugaron en el mundo político de los reinos hispánicos en la Plena y Baja Edad Media; la parte tercera analiza la presencia de María en el Nuevo Mundo, transportada allí por los conquistadores, y la importancia de su impacto en los siglos XVI y XVII.

Esta obra es en primer lugar un magnífico estudio del papel de la Virgen María en la Edad Media hispana, pero los argumentos utilizados hacen de esta obra un estudio que va mucho más allá, es decir, se podría calificar de un estudio de la historia de la España medieval tomando como eje conductor la figura de María. También se podría calificar de magnífico ejemplo de estudio de la "geografía mariana de la España cristiana". El desarrollo del culto a la Virgen María en Europa, fundamentalmente a partir del siglo XII, coincide con la lucha de los reinos cristianos del Norte peninsular contra los musulmanes; Amy Remensnyder enfoca los reinos hispánicos medievales y se adelanta al siglo XI, cuando la lucha contra los árabes en el territorio de la Península Ibérica se intensificó y se consiguieron avances muy importantes. La autora ha estudiado minuciosamente las fuentes con las que ha podido defender los argumentos que utiliza para resaltar el papel de la Virgen en los distintos escenarios temporales y espaciales que contempla. Su atento análisis de las fuentes le ha permitido desarrollar un amplísimo estudio del papel de María, algo que no se había hecho con la profundidad que se hace en este libro. Se han hecho, por ejemplo, excelentes estudios sobre las Cantigas de Santa María y el papel que la Virgen tuvo en el conjunto de la obra alfonsí, pero no se ha planteado un estudio de un panorama tan amplio como el que se contempla en este libro.

El acierto en la búsqueda de las fuentes primarias aparece desde el principio de la obra. La autora utiliza el Libre de Sancta Maria de Ramón LLull que, a finales del siglo XIII, dibujaba a una Virgen poderosa en las batallas, esperanza de los caballeros, a cuya ayuda era imprescindible acudir para ganar las contiendas. Acudiendo a algunas historias, Remensnyder defiende que LLull se limitaba a poner por escrito lo que se había ido convirtiendo en creencia generalizada en los dos siglos anteriores: María se encontraba entre las fuerzas que ayudaban a ganar las batallas a los ejércitos cristianos, consiguiendo arrebatar bocados importantes al territorio de los árabes. Compara la protección de la Virgen a la protección de Santiago, sin que se encontrara en la necesidad de montar a caballo y aparecerse en las batallas.

La autora hace un recorrido por batallas y ciudades importantes en el avance reconquistador hacia el Sur, con el foco puesto en el papel de María en ese avance. Entre las batallas, Remensnyder destaca la de Las Navas de Tolosa (1212) en la que el estandarte del rey Alfonso VIII tenía la imagen de María llevando en brazos a su hijo Jesús. Desde entonces los cronistas señalaron la deuda con la Virgen, pues defendían que el triunfo en la batalla se debía a su intervención y protección. Entre los lugares y ciudades que la autora destaca está la fundación del Real Monasterio de Santa María de las Huelgas, que utiliza para defender su argumento de la conexión de la figura de María con la monarquía medieval de los reinos 
hispánicos. En esa línea no se olvida del rey que convirtió a María en "reina sin igual” y para quien la Virgen fue fuente de inspiración fundamental: Alfonso X del sabio. El nombre de María empieza a utilizarse en iglesias y catedrales según se fue avanzando en la reconquista del territorio. Buen ejemplo es Toledo, la ciudad que tomó Alfonso VI en 1085 y que vio convertida su mezquita en catedral con el nombre de Santa María.

La autora no se conforma con utilizar las fuentes cronísticas y literarias para sostener sus argumentos, acude también a la iconografía. Sirvan de ejemplo los cuadros que analiza de la época de los Reyes Católicos, y en los que encuentra interesantes interpretaciones de la obra política de estos monarcas. Examinando la pintura titulada "La Virgen de los Reyes Católicos", Remensnyder vislumbra una visión política en la que Fernando e Isabel parecen actuar de acuerdo con los deseos de la Virgen. Su recorrido por la historia de los primeros tiempos del reinado de Fernando e Isabel es una buena muestra de la metodología utilizada por la autora, que no se conforma con una simple descripción del cuadro sino que va más allá y trata de explicar a través de la imagen la situación política por la que pasaron los reyes, considerando entre otros aspectos la ayuda que la Virgen María ofreció a Isabel en su lucha contra la heredera legítima de la corona de Castilla, Juana la Beltraneja. En otro cuadro en el que aparece la Madonna María rodeada de los Reyes Católicos, el análisis de la autora va aún más lejos pues apunta que "dado el lugar de María en la ideología de la cruzada de Granada, no sorprende que el rey y la reina sintieran su presencia cuando tocaron el campo".

Si es una novedad este estudio minucioso de Amy Remensnyder, en el que resalta la figura de María como ideal de mujer para los caballeros cristianos, resulta aún más novedoso la utilización que hace de la figura de la Virgen en relación con los creyentes de las otras dos religiones que ocuparon el solar hispano durante la Edad Media. En el capítulo titulado "los enemigos de María, los amigos de María", la autora entra a analizar historias utilizadas para mostrar el papel de la Virgen en la defensa de los cristianos en su lucha contra los musulmanes, quienes no siempre consideraban a María enemiga, sino, al contrario, la tenían un respeto considerable como muestran los retratos que de ella hacían poetas de la categoría de Ibn Hazem, u otros poetas andalusíes que la admiraban y querían incorporarla a sus cortes. Estos poetas de Al Andalus seguían la sura 3:42 de El Corán que dice: "Oh María, Dios te ha favorecido y hecho inmaculada, y te ha elegido entre todas las mujeres del mundo". Remensnyder no deja fuera del foco a los judíos, a los que observa dentro del conflicto que aparece en algunas Cantigas de Santa María: "la Santa Virgen María con la que los judíos tienen gran guerra"; la autora utiliza la obra litúrgica Gaude María Virgo para enfatizar este tema.

El análisis de la posición de musulmanes y judíos respecto a la Virgen que contempla la relación de María con las tres religiones de la Iberia medieval, se corona con un capítulo dedicado a María como "madre de conversión". Los milagros de la conversión de judíos o musulmanes al cristianismo son analizados como parte de la obra de la Virgen María, a la que debían la gracia del bautismo hombres y mujeres de las otras dos religiones. Los ejemplos que la autora utiliza están muy bien buscados y son muy interesantes.

Por otra parte, no solo son interesantes los ejemplos relacionados con las minorías religiosas, sino que, en general, la selección de los ejemplos utilizados en este libro es magnífica. Según se va avanzando en su lectura se puede comprobar que las referencias elegidas por la 
autora no solo valen para probar sus hipótesis de trabajo, sino que sirven como textos independientes, muy ilustrativos e interesantes de leer.

La lectura de un libro largo suele plantear el problema de cansancio al lector. No es este el caso de este libro, que tiene el mérito de ir ganando en interés según van pasando las páginas del libro, y de llegar a la tercera parte que es interesantísima. Como la entrada de los españoles en América y el comienzo de la obra conquistadora fue paralela a la obra evangelizadora, no es de extrañar que los colonizadores llevaran con ellos a la "conquistadora". Muy pronto, hombres como Cortés se presentaron ante los indígenas con imágenes de la Virgen en estandartes o pequeñas estatuas. Pero el arraigo definitivo, o la conexión definitiva, tuvo lugar con motivo del asedio a Tenochtitlan por Cortés, cuyos hombres consiguieron hacer huir a los habitantes de esa ciudad azteca con la ayuda de la Virgen, o, al menos, eso creían ellos. Muy pronto, pues, la figura de María consiguió un lugar prominente en el Nuevo Mundo, y no solo entre los conquistadores, sino entre los indígenas. El papel de María en un mundo en el que esa figura no tenía tradición alguna, lejana en el espacio y en el tiempo, fue muy importante, consiguió un impacto singular de la mano de los conquistadores; éstos lucharon para arrebatar las deidades tradicionales indígenas, al tiempo que arrebataban mujeres que necesitaban para hacer crecer la sociedad que estaban construyendo. María era un modelo para todos: para los guerreros y para sus mujeres, para ellos por presentarla como guerrera de cualidades extraordinarias, para ellas por exhibirla como madre amantísima y misericordiosa.

En un libro que cubre tantos siglos y dos hemisferios, que expone cientos de ejemplos, que utiliza fuentes primarias y secundarias con gran maestría, se han deslizado algunas erratas (como señalar el sitio de Nájera como parte de Cataluña), así como afirmaciones que podrían ser discutibles (como que Ramón Llull había visto mucha guerra). Sin embargo, esas erratas quedan enterradas, casi imperceptibles, en una obra de erudición extraordinaria, con un panorama lleno de detalles que, aunque innecesarios para un lector español o hispanoamericano, pueden ser especialmente esenciales y útiles para un lector americano o de otras latitudes.

Por último, se ha de resaltar el aspecto literario del libro, escrito con un lenguaje muy cuidado, elegante y mimado por la autora. Ello, unido a la forma poco convencional de presentar el tema, hacen del libro una obra diferente, excelente y original en el fondo y en la forma, que cubre un hueco que no se había percibido y que seguiría sin verse de no haberlo descubierto, para luego cerrarlo, Amy Remensnyder. 